\title{
Elucidating human male germ cell development by studying germ cell cancer
}

\author{
Daniel Nettersheim, Sina Jostes, Simon Schneider and Hubert Schorle \\ Department of Developmental Pathology, Institute of Pathology, University of Bonn Medical School, \\ Bonn, Germany
}

Correspondence should be addressed to H Schorle; Email: Hubert.Schorle@ukb.uni-bonn.de

\begin{abstract}
Human germ cell development is regulated in a spatio-temporal manner by complex regulatory networks. Here, we summarize results obtained in germ cell tumors and respective cell lines and try to pinpoint similarities to normal germ cell development. This comparison allows speculating about the critical and error-prone mechanisms, which when disturbed, lead to the development of germ cell tumors. Short after specification, primordial germ cells express markers of pluripotency, which, in humans, persists up to the stage of fetal/infantile spermatogonia. Aside from the rare spermatocytic tumors, virtually all seminomas and embryonal carcinomas express markers of pluripotency and show signs of pluripotency or totipotency. Therefore, it appears that proper handling of the pluripotency program appears to be the most critical step in germ cell development in terms of tumor biology. Furthermore, data from mice reveal that germline cells display an epigenetic signature, which is highly similar to pluripotent cells. This signature (poised histone code, DNA hypomethylation) is required for the rapid induction of toti- and pluripotency upon fertilization. We propose that adult spermatogonial cells, when exposed to endocrine disruptors or epigenetic active substances, are prone to reinitiate the pluripotency program, giving rise to a germ cell tumor. The fact that pluripotent cells can be derived from adult murine and human testicular cells further corroborates this idea.

Reproduction (2016) 152 R101-R113
\end{abstract}

\section{Normal germ cell development}

Germ cells (GCs) are the progenitor cells of sperm and oocytes, which are a prerequisite for the development of new life. GC development is initiated early during embryogenesis. In mice, few cells of the proximal epiblast acquire GC competence by BMP2, BMP4 and BMP8B stimuli (Hayashi et al. 2007). These primordial germ cell (PGC) precursors escape the somatic differentiation program and are specified by upregulation of PRDM1/BLIMP1, PRDM14 and Fragilis (Hayashi et al. 2007, Saitou et al. 2012). The PGCs migrate along the developing hindgut to the genital ridges, which eventually differentiate into testes or ovaries. During this migration, PGCs undergo crucial changes, like a G2-arrest, global DNA demethylation and erasure of imprinted genes as shown in mice and partially for humans (Saitou \& Yamaji 2012, Meyenn \& Reik 2015).

After arrival in the genital ridge, the GCs undergo a transition, which prepares them for meiosis. This phase is denominated 'licensing' and is controlled by the RNAbinding protein DAZL (deleted in azoospermia like) (Lin et al. 2008). In the C57/Bl6 strain of mice, it was shown that DAZL-deficient PGCs migrate to the gonad, but fail to respond to feminizing or masculinizing cues leading to a failure of oogenesis or spermatogenesis respectively (Gill et al. 2011).

As observed in mice, male sexual differentiation is initiated by the Sry gene (sex determining region on the Y chromosome), which triggers the expression of Sox9 and therewith Sertoli cell differentiation that is essential for proper testis development (Kashimada \& Koopman 2010). In females, ovarian development is supported by inhibition of the SOX9 signaling cascade via beta-catenin and FOXL2, respectively (Kashimada \& Koopman 2010). The expression of CYP26B1, a member of the cytochrome p450 family, prevents developing male embryonic germ cells from a premature initiation of meiosis (Koubova et al. 2006, Kumar et al. 2011).

Data dealing with the molecular mechanisms leading to PGC specification in humans are scarce. However, studies have demonstrated that human and murine germ cells display a highly similar expression profile like OCT3/4, NANOG, BLIMP1 and TFAP2C. However, two main differences have been reported so far. Using 'in vitro' differentiation protocols, SOX17 was identified as a key player of human PGC fate inducing PRDM1 expression and downstream GC genes (Irie et al. 2015). 
Vice versa, human PGCs lack the expression of the pluripotency marker SOX2, which is expressed in murine PGCs aside with OCT3/4 and NANOG (Perrett et al. 2008). Further, PRDM14, which is essential for murine PGC maintenance, shows only low levels of expression in human PGC-like cells and seminomatous TCam-2 cells, which also share a similar gene expression profile with PGCs (Irie et al. 2015, Nettersheim et al. 2015, Sugawa et al. 2015, Tang et al. 2015).

In human males, undifferentiated GCs $\left(\mathrm{A}_{\text {dark }}{ }^{-}\right.$ spermatogonia), which are discussed to be the testicular stem cells, settle down at the basement membrane of the developing seminiferous tubules (Clermont 1966). They give rise to $A_{\text {pale }}$-spermatogonia, which divide mitotically and differentiate into B-spermatogonia (de Rooij 2001). These diploid B-spermatogonia eventually initiate meiotic divisions of spermatogenesis. In a step-wise process, four haploid spermatids are formed out of each diploid B-spermatogonium. Accordingly, self-renewing testicular stem cells in mice are described as $\mathrm{A}_{\text {single }}{ }^{-}$ spermatogonia, which progress into $A_{\text {paired }}{ }^{-}$and $A_{\text {aligned }}{ }^{-}$ spermatogonia (de Rooij 2001). The differentiation into mitotically active $A_{1}-A_{4}$ spermatogonia marks the entry into spermatogenesis, giving rise to $B$-spermatogonia (de Rooij 2001). With the onset of puberty and increased retinoic acid (RA) signaling, B-spermatogonia develop into spermatocytes that undergo meiotic divisions to generate haploid spermatids (Bowles \& Koopman 2007). These spermatids enter the process of spermiogenesis/ spermatohistogenesis, putatively involving genes like AEP1, GOPC, PICK1, MNS1 and TAF7L (Yao et al. 2002, Luk etal. 2006, Xiao et al. 2009, Zhou etal. 2013). Finally, the majority of histones are replaced by protamines resulting in DNA hypercondensation (Balhorn 2007). Development of the flagellum and the acrosome gives sperm cells their characteristic morphology, necessary for full functionality, i.e. motility and penetration of the egg respectively.

\section{Germ cell malignancies}

Germ cell tumors (GCTs) are subdivided into different types $(I-V)$, depending on cell of origin, sex of the patient, age of diagnosis, growth/differentiation behavior and morphology (Oosterhuis \& Looijenga 2005).

Type I GCTs occur during early childhood and present mainly as non-seminomas (embryonal carcinomas (EC), teratomas and yolk-sac tumors). They are thought to originate directly from a PGC or gonocyte and, therefore, do not contain the precursor lesion germ cell neoplasia in situ (GCNIS) (Fig. 1A).

Type II GCTs arise via a GCNIS (also referred to as: carcinoma in situ (CIS); intratubular germ cell neoplasia unclassified (IGCNU)) (Fig. 1A) (Berney et al. 2016). Although not formally proven, the generally accepted hypothesis is that GCNIS cells represent arrested PGCs, which had acquired genetic or epigenetic aberrations
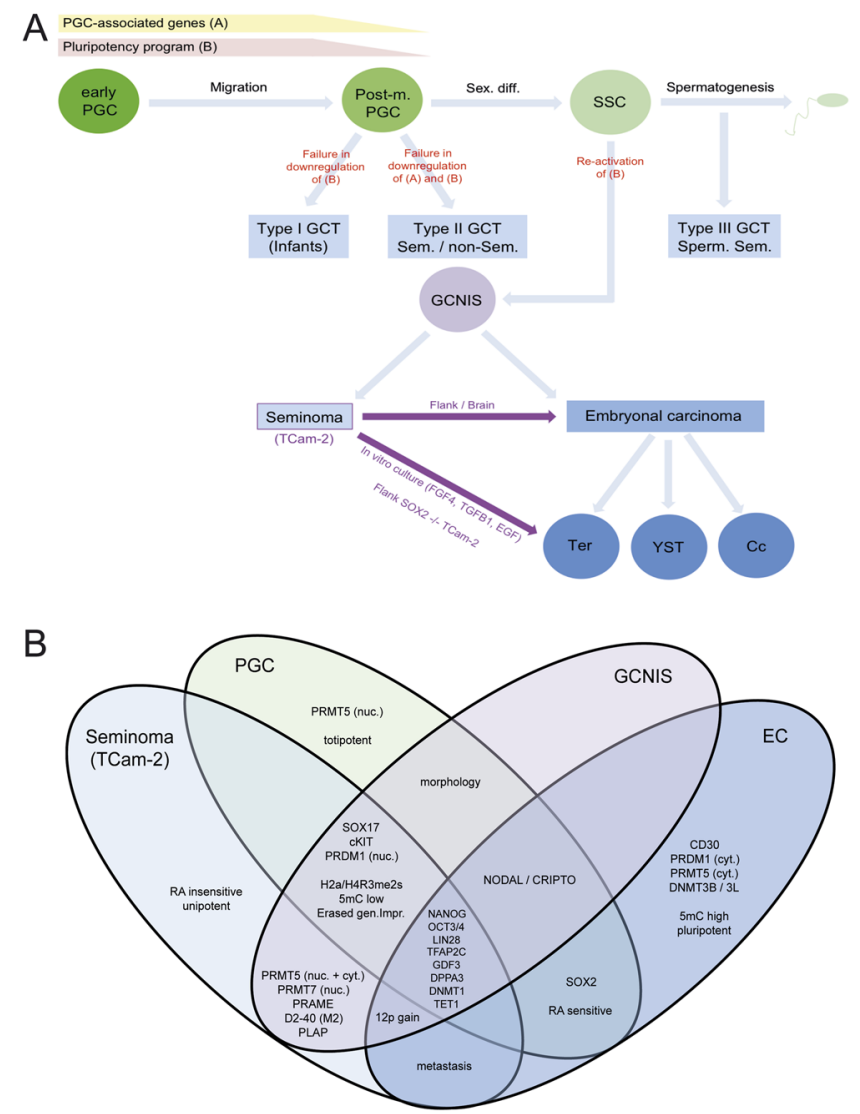

Figure 1 (A) Model of GCT development from PGCs. (B) Venn diagram summarizing commonly shared gene expressions and cellular/ molecular features between PGCs, GCNIS, seminomas and ECs.

(Skakkebaek et al. 1987, Hoei-Hansen et al. 2005) (Fig. 1A). Morphologically, GCNIS cells resemble PGCs, i.e. they appear round with a big, round nucleus and a clear cytoplasm and grow uniformly within the confines of the seminiferous tubules. GCNIS and PGCs further share a similar gene expression profile, i.e. expression of pluripotency-related genes LIN28, OCT3/4 and NANOG as well as PGC markers PRDM1/BLIMP1, TFAP2C and CKIT (Fig. 1B). Within 5 (50\% of cases) to $7(70 \%$ of cases) years, GCNIS lesions eventually develop into a seminoma or a non-seminoma (Fig. 1A) (Giwercman \& Skakkebaek 1993).

Seminomas are considered to be the default developmental pathway of GCNIS, since they show only limited differentiation abilities (Oosterhuis \& Looijenga 2005, de Jong et al. 2008). Like GCNIS and PGCs, seminoma cells display a big round nucleus and a clear cytoplasm, but appear more polygonal in shape. They further share the gene expression profile of PGCs, expressing the pluripotency markers LIN28, OCT3/4 and NANOG and the germ cell markers PRDM1, CKIT, TFAP2C as well as PLAP. In addition, they express SOX17 and D2-4O (Fig. 1B). The non-seminomas initially present as ECs and display features of totipotency: They are able to differentiate into all three germ layers 
(meso-, endo-, ectoderm) as well as extraembryonic tissues, thereby giving rise to teratomas, yolk-sac tumors and choriocarcinomas (Oosterhuis \& Looijenga 2005) (Fig. 1A). ECs share expression of TFAP2C (variable), GDF3 (high in EC), DPPA3 (high in EC), OCT3/4 and NANOG with seminomas and/or GCNIS, but additionally express DNMT3B, DNMT3L, NODAL, CRIPTO, CD30 and SOX2 (Hoei-Hansen et al. 2004, Almstrup et al. 2005, Ezeh et al. 2005, de Jong et al. 2008) (Fig. 1B). Furthermore, ECs show only weak to absent expression of CKIT as well as cytoplasmic localization of PRDM1 (Rajpert-De Meyts \& Skakkebaek 1994, Leroy et al. 2002, Almstrup et al. 2005, Eckert et al. 2008) (Fig. 1B). Outside the testis, type II GCTs are found mainly along the body mid-line, the thymus and the brain (Utz \& Buscemi 1970, Johnson et al. 1976, Bassetto et al. 1995, Oosterhuis \& Looijenga 2005).

Common to the vast majority of GCTs is an amplification of the short arm on chromosome 12 (12p gain), mainly caused by isochromosome formation (Rosenberg et al. 1998, Oosterhuis \& Looijenga 2005) (Fig. 1B). So far, $12 \mathrm{p}$ gain was detected predominantly in invasive GCT samples. Therefore, it is believed that amplification of this chromosomal region occurs during invasive growth of GCTs (Rosenberg et al. 2000, Summersgill et al. 2001). Nevertheless, amplification of $12 p$ was also detected in some GCNIS cases in tubules adjacent to tumors, when the invasive process likely has begun (Ottesen et al. 2003). Since the amplified region on chromosome 12 encodes for the pluripotency- and PGC-related genes NANOG, GDF3 and DPPA3 (Ezeh et al. 2005), gain of these genes might contribute to the invasive capacities of GCTs.

Type III GCTs, the spermatocytic tumor are detected in the 5th-6th decade of life and are a rare GCT $(<1 \%$ of testicular tumors) (Looijenga \& Oosterhuis 1999, Oosterhuis \& Looijenga 2005, Raiss et al. 2011) (Fig. 1A). It is hypothesized that spermatocytic tumors originate from germ cells that are capable of maturing at least to spermatogonia/pachytene spermatocytes, since these GCTs express typical pachytene spermatocyte markers like SCP1, XPA and SSX (Aggarwal \& Parwani 2009). Screening for oncogenic driver mutations in spermatocytic tumors revealed genetic aberrations in the FGFR3 and HRAS gene (Goriely et al. 2009). Goriely and coworkers demonstrated by parallel sequencing of sperm DNA that occurrence of these mutations increases with paternal age, arguing for a category of the so-called paternal age effect mutations (Goriely et al. 2009). These mutations are thought to occur in spermatogonia. Owing to the proliferative capacities of the FGFR3- and HRAS-involved signaling pathways, it is believed that these mutations then selectively become enriched during clonal expansion of spermatogonia (Goriely et al. 2009). Spermatocytic tumors typically consist of three cell types: small, medium and large size, which morphologically resemble spermatogonia or spermatocytes with round and sometimes multinucleated nuclei (Oosterhuis \& Looijenga 2005). As in type I GCTs, GCNIS cells are not present in spermatocytic tumors (Aggarwal \& Parwani 2009). Spermatocytic tumors are negative for classical seminoma or EC markers, like PLAP, OCT3/4 and CD30, but sometimes positive for CKIT and VASA (Oosterhuis \& Looijenga 2005, Aggarwal \& Parwani 2009). In contrast to classical seminomas and other type II GCTs, spermatocytic tumors display gain of chromosome 9 or $\mathrm{X}$, but show no isochromosome $12 \mathrm{p}$ formation (Rosenberg et al. 1998, Verdorfer et al. 2004, Reuter 2005).

\section{Type I and type II GCTs: results of a flawed licensing}

As mentioned, after specification, PGCs initiate the expression of germ cell and pluripotency markers. After arrival of the PGCs in the genital ridge, they prepare for gametogenesis; this stage is called 'licensing' (Gill et al. 2011). During licensing, the genes Dazl, Ddx4 and Dmrt1 are induced and repress the PGC-specific genes and the pluripotency markers. This is evident in Dazl mutants, where expression of pluripotency markers persists and the germ cells eventually initiate apoptosis (Lin \& Page 2005). Interestingly some of the gonadal cells in Dmrt1 mutants, as well as in animals heterozygous for Tfap2C and Nanos3 also fail to downregulate pluripotency markers after arrival in the genital ridge in the 129 genetic background (Krentz et al. 2013, Schemmer et al. 2013). In these mutants, the persistence of Nanog and Oct3/4 as well as other PGC and pluripotency marker genes like Dnd1, Prdm14, Lin28, cKit and Dppa3 counteracts apoptosis leading to rapid development of a germ cell tumor equivalent to a type I GCT, an early childhood tumor (Kehler et al. 2004, Western 2009, Pirouz et al. 2012). These data in mice suggest that interference with genes involved in downregulation of the pluripotency genes after arrival in the genital ridge is a critical (and error-prone) step. According to these findings, human type I germ cell tumors might be initiated during licensing, when arriving PGCs downregulate the PGC-specific genes but fail to downregulate the pluripotency markers. A similar mechanism might apply to extragonadal GCTs (germinomas and non-germinomas). There, misrouting of the cells prevents them from entering the genital ridge. The cells eventually initiate apoptosis, since they are deprived of their growth and guidance factors. The misrouted GCs are not confronted with the somatic cells of the genital ridge and never encounter the crosstalk leading to initiation of the licensing cascade. If they survive and persist, they might give rise to extragonadal GCTs.

Similar to Type I GCTs, the pre-GCNIS and the GCNIS of the type II GCTs is also initiated at licensing. Here, the arriving PGCs not only maintain expression of the 
pluripotency genes, but also retain expression of SOX17, PRDM1 and PRMT5 (Eckert et al. 2008). Recent data indicate that in humans, SOX17 is a critical determinant of PGC fate transactivating expression of PRDM1 (Irie et al. 2015). In turn, PRDM1 and PRMT5 proteins cooperate to establish a symmetric dimethylation at arginine 3 of histones $\mathrm{H} 2 \mathrm{a}$ and $\mathrm{H} 4(\mathrm{H} 2 \mathrm{a} / \mathrm{H} 4 \mathrm{R} 3 m e 2 \mathrm{~s})$, leading to suppression of somatic differentiation (Ohinata et al. 2005, Ancelin et al. 2006). Since such cells remain as undifferentiated GCNIS in the developing testicular environment for years, we speculate that the SOX17PRDM1 cascade not only blocks further differentiation along the germ cell fate but also maintains a survival signal and renders the cells in proliferative dormancy.

Therefore, these data indicate that 'licensing' is a critical step in germ cell biology where the pluripotency and the PGC program must be suppressed for proper germ cell development to proceed.

\section{Germinoma: misrouting of germ cells by defects in CKIT or CXCR4}

Type II GCTs can also be found in thymus and brain, where they are termed germinoma (Oosterhuis \& Looijenga 2005). It is assumed that intracranial germinomas, which are highly similar to the histology of seminomas arise from PGCs that failed to enter the genital ridges during embryogenesis. PGCs positive for the receptor tyrosine kinase CKIT migrate along an SCF gradient to the genital ridges (Runyan et al. 2006, Gu et al. 2009). After arrival at the developing gonadal site, cKIT expression is downregulated. Therefore, it is conceivable that auto-activating mutations of the CKIT gene (exon 17: D816V, D816H, N822K, Y823D; exon 11: L576P, W557C), rendering CKIT expression independent of SCF, might cause erroneous migration of PGCs, eventually leading to formation of intracranial germinomas (Przygodzki et al. 2002, Kemmer et al. 2004, WillmorePayne et al. 2006, Biermann et al. 2007). Sakuma and coworkers and Kamakura and coworkers demonstrated CKIT expression in all germinomas or germinomatous components of mixed non-germinomas (Sakuma et al. 2004, Kamakura et al. 2006). Additionally, Sakuma and coworkers found that $25 \%$ of all germinomas analyzed harbored an autoactivating CKIT mutation at exon 11 or 17, while Kamakura and co-workers detected mutated CKIT in 23\% of germinomas (exon 2 (E73K, T96M), 11 (V560D), 13 (A636V), 17 (D816Y)) (Sakuma et al. 2004, Kamakura et al. 2006). These mutation rates are very similar to the $C K I T$ mutation rates found in classical seminoma (24.1\%) (Sakuma et al. 2003, Kemmer et al. 2004). Thus, autoactivating CKIT mutations might lead to an SCF-independent migrational path of the PGCs, leading to formation of intracranial germinomas.

An alternative mechanism represents the chemokinemediated CXCR4 pathway, which is activated by selective binding of CXCL12. Increased activity of the CXCR4 pathway correlates to an increased risk to develop metastases and stimulates tumor proliferation, invasiveness as well as angiogenesis (Guan et al. 2015, Ma et al. 2015). CXCR4-positive PGCs migrate along somatic sites expressing CXCL12 (Ara et al. 2003, Molyneaux et al. 2003, Gilbert et al. 2009, Takeuchi et al. 2010). CXCR4-positive GCTs mainly metastasize to sites with CXCL12 expression. Gilbert and coworkers demonstrated that expression of CXCR4 is high in seminomas and in the seminoma cell line TCam-2 compared with normal testis (Gilbert et al. 2009). They demonstrated further that TCam-2 cells start to migrate in response to CXCL12, while CXCR4-negative 2102EP cells do not. Since it has been demonstrated that TCam-2 cells cluster close to human PGC-like cells, it seems reasonable to assume that human PGCs use both CKIT and CXCR4/CXCL12 for migration (Irie et al. 2015, Tang et al. 2015).

\section{GCT cell lines as model to study germ cell development and malignancy}

Several human GCT cell lines have been established in order to generate suitable model systems for in vitro studies: Most of them are derived from ECs and, therefore, share pluripotent or nullipotent characteristics (i.e. 2102EP, NCCIT; Table 1). In addition, cell lines have been established from choriocarcinomas (JEG-3, JAR and BeWo; Table 1), resembling differentiated non-seminomas. From seminoma patients, three cell lines have been derived so far, namely TCam-2, JKT-1 and SEM-1 (Table 1) (Mizuno et al. 1993, Kinugawa et al. 1998, Russell et al. 2013). Thorough analyses revealed that TCam-2, but not JKT-1 cells, resemble seminoma in vitro (de Jong et al. 2008, Eckert et al. 2008, Nettersheim et al. 2012), while SEM-1 cells show intermediate characteristics between seminoma and nonseminoma (Russell et al. 2013).

EC cell lines have long been used as a proxy for embryonic stem cell (ESC) research, owing to their similarities in marker expression, their extended selfrenewal capacities and their ability to differentiate into a wide range of cell types (Thomson 1998, Chaerkady et al. 2010, Pera et al. 2000). Today EC cell lines still represent a valuable in vitro model for studying pluripotency and stem cell regulatory networks particularly in testicular tumors, in order to identify novel targets for GCT therapy.

Seminomas and the seminoma-derived cell line TCam-2 closely resemble PGCs. Like PGCs, TCam-2 cells express pluripotency markers LIN28, NANOG, OCT3/4 and PGC markers PRDM1, TFAP2C, DMRT1 as well as CKIT (Eckert et al. 2008, Nettersheim et al. 2011a, 2012) (Fig. 1B). In humans, PGCs express SOX17 (Campolo et al. 2013), which is also detected in GCNIS/ seminoma and TCam-2 cells (Irie et al. 2015) (Fig. 1B). 
Table 1 Summary of available GCT cell lines.

\begin{tabular}{|c|c|c|c|c|}
\hline Cell line & Origin & Growth in vitro as... & Growth in vivo as... & Reference \\
\hline TCam-2 & Seminoma & Seminoma & $\begin{array}{l}\text { EC (Flank), CIS/Seminoma } \\
\text { (Testis) }\end{array}$ & Mizuno et al. (1993) \\
\hline JKT-1 & Seminoma, EC & Sem/EC-intermediate & Seminoma & Kinugawa et al. (1998) \\
\hline SEM-1 & Seminoma & Sem/EC-intermediate & mediastinal GCC & Russell et al. (2013) \\
\hline $1411 \mathrm{HP}$ & Semimoma, EC, Teratoma, YST & EC & EC, YST & Vogelzang et al. (1985) \\
\hline $169 \mathrm{~A} / 218 \mathrm{~A} / 228 \mathrm{~A} / 240 \mathrm{~A}$ & EC & $\mathrm{EC}$ & n.d & Houldsworth et al. (1997) \\
\hline $1777 \mathrm{~N}$ & $\begin{array}{l}\text { Retroperitoneal metastasis of } \\
\text { non-sem. }\end{array}$ & $\mathrm{EC}$ & EC & Bronson et al. (1983) \\
\hline 2102EP & EC, Teratoma & $\mathrm{EC}$ & EC & Andrews (1982) \\
\hline 833Ke & Seminoma, EC, Teratoma, CC & $\mathrm{EC}$ & $\mathrm{EC}$ & Bronson et al. (1980) \\
\hline GCT27 & EC, Teratoma & $\mathrm{EC}$ & EC, Teratoma, YST & Pera et al. (1987) \\
\hline GCT35 & EC, Teratoma & $\mathrm{EC}$ & EC, YST & Pera et al. (1987) \\
\hline GCT44/46/72 & EC, Teratoma & $\mathrm{EC}$ & YST & Pera et al. (1987) \\
\hline GCT48 & EC, Teratoma & $\mathrm{EC}$ & EC & Pera et al. (1987) \\
\hline $\mathrm{H} 12.1 / .5 / .7$ & Seminoma, EC, Teratoma, CC & $\mathrm{EC}$ & $\mathrm{EC}$ & Casper et al. (1987) \\
\hline NCCIT & EC, Teratoma & $\mathrm{EC}$ & EC, Teratoma & Damjanov et al. (1993) \\
\hline NEC-8/-14/-15 & EC, YST, CC & $\mathrm{EC}$ & EC, Teratoma & Sekiya et al. (1985) \\
\hline SuSa & EC, Teratoma & $\mathrm{EC}$ & n.d. & Hogan et al. (1977) \\
\hline TERA1/2 & EC, Teratoma & EC & $\mathrm{EC}$ & Andrews et al. (1984) \\
\hline 577MF/L/RPLN & Metastasis of non-sem. & Undifferentiated carcinoma & Teratoma & Wang et al. (1980) \\
\hline BeWo & $\mathrm{CC}$ & $\mathrm{CC}$ & $\mathrm{CC}$ & Pattillo \& Gey (1968) \\
\hline JAR & $\mathrm{CC}$ & CC & CC & Hochberg et al. (1992) \\
\hline JEG-3 & $\mathrm{CC}$ & $\mathrm{CC}$ & $\mathrm{CC}$ & Kohler \& Bridson (1971) \\
\hline
\end{tabular}

Using a murine system allowing for differentiation of PGC-like cells from embryonic stem cells (ESCs), Nakaki and coworkers defined a set of 75 genes as 'core' PGC genes (Nakaki et al. 2013). Meta-analysis of expression microarray analyses demonstrated that many of these genes are also expressed in human GCNIS, seminoma, EC and teratoma tissues as well as TCam-2 cells (Fig. 2A, B, C and D) (Biermann et al. 2007, Eckert et al. 2008). A Venn diagram illustrates that 14 of these 'core' PGC genes are commonly expressed in these samples with an expression intensity threshold $\geq \log _{2} 10$, namely $C K I T, K L F 2$, DPPA3, PYGL,
TCL1, CKB, BRPF3, SORBS1, KCTD15, HEY1, RGS16, $A P 3 B 2, G R H L 3$ and TDH (Fig. 2E and F).

Furthermore, a meta-analysis of genome-wide gene expression between TCam-2 and murine male/female PGCs at embryonic developmental days 11.5, 12.5 and 13.5 (data from (Jameson et al. 2012) (expression intensity threshold $\left.\geq \log _{2} 10\right)$ ) demonstrates that the majority of genes expressed in male or female PGCs are also detectable in TCam-2 cells $(n=1022)$ (Fig. 3A, B and C). A comparison of these 1022 genes with the gene expression data of GCNIS, seminomas and ECs shows that 690 genes are also expressed in these GCT entities
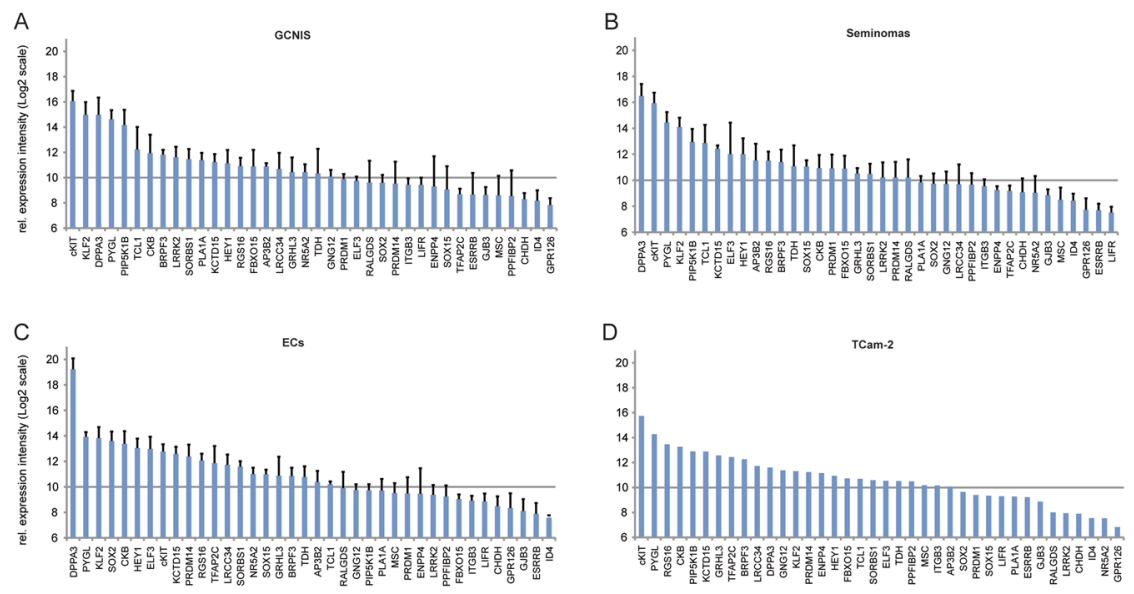

E

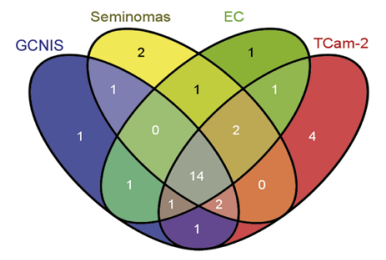

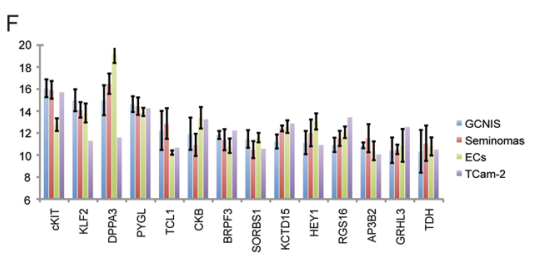

Figure 2 (A, B, C and D) Microarray expression analysis of 'core' PGC genes as defined by Nakaki and coworkers (2013) in GCNIS $(n=3)$, seminoma $(n=4)$ and EC $(n=3)$ tissues as well as TCam-2 cells $(n=1)$. Standard deviation is given above the graphs. (E) Venn diagram of commonly expressed 'core' PGC genes. Cut-off $=$ expression intensity $<\log _{2} 10$. (F) Expression intensity of the 14 commonly expressed 'core' PGC genes in indicated GCT tissues and cell lines. Standard deviation is given above the graphs. 

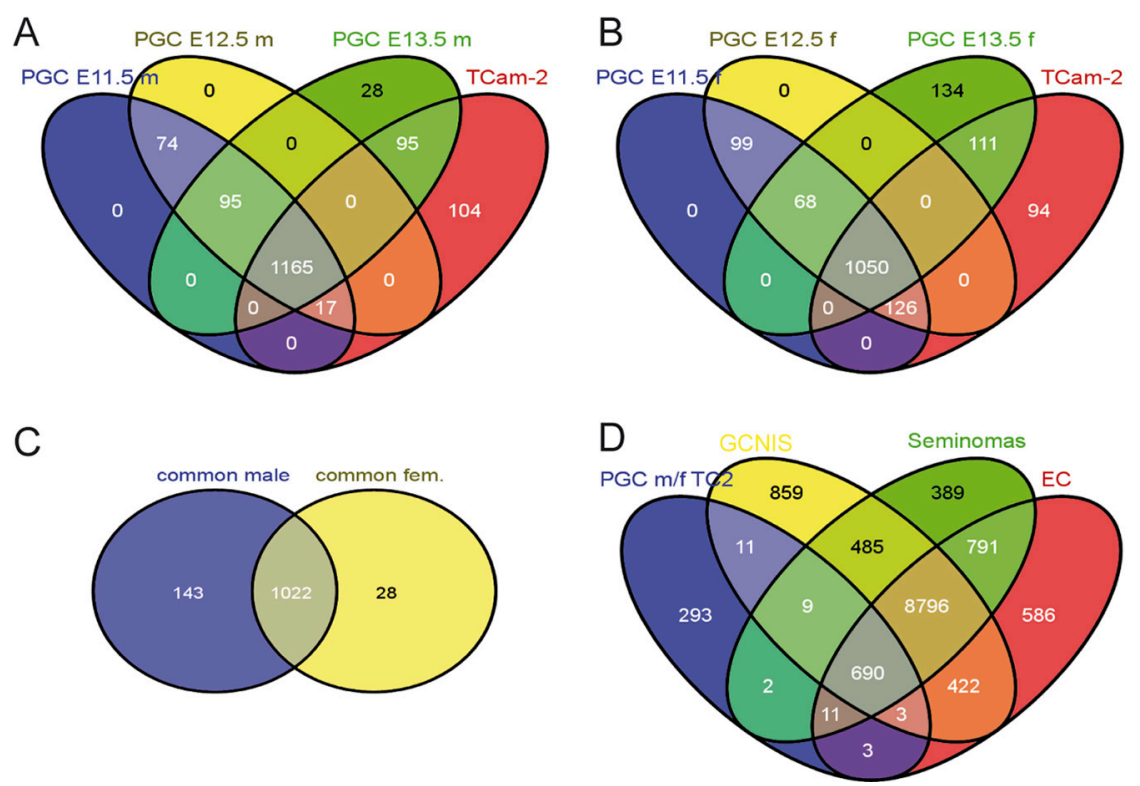

Figure 3 ( $A$ and $B$ ) Venn diagrams illustrating commonly expressed genes in TCam-2 and male (A) as well as female (B) PGCs at different developmental time points (E11.5, E12.5, E13.5). (C) A Venn diagram summarizes commonly expressed genes (1022) between TCam-2 and both male and female PGCs. (D) 690 of these 1022 are also expressed in GCNIS, seminomas and ECs. Venn diagrams were created with Venny 2.1 (www.bioinfogp. cnb.csic.es).

(expression intensity threshold $\geq \log _{2} 10$ ) (Fig. 3D). Recently, Irie and coworkers reported that human ES-derived PGC-like cells share a transcriptional profile with TCam-2 seminoma-like cells (Irie et al. 2015). These data point out that PGCs, GCC tissues (GCNIS, seminomas, ECs) and TCam-2 cells are closely related to each other and that TCam-2 cells clearly represent a suitable PGC model in vitro.

In mice, development of GCNIS and seminomas are not observed, but the orthotopical transplantation of TCam-2 cells into the murine seminiferous tubules results in the formation of a GCNIS/seminoma. Thus, this approach represents a valuable strategy for the study of human seminomas in vivo (Nettersheim et al. 2012) (Fig. 1A).

Taken together, GCT-derived cell lines display a wide variety of phenotypes, from being close to PGC (TCam2 ), close to ESC (EC lines) or differentiated in a variety of tissues. Expression of the pluripotency network is detected in seminomas, ECs and derived cell lines. Thus, regulation and timely repression of genes involved in pluripotency appears to be the most critical step in germ cell development.

\section{Regulation of PRDM1 by LIN28 in PGCs and GCTs}

In addition to SOX17, PRDM1 levels seem to be controlled by LIN28. Lin28 is a repressor of miRNA let7 (miR-let7) and miR-let7 in turn represses Prdm1. Thus, expression of Lin28 is essential for proper murine PGC development (Newman et al. 2008, West et al. 2009). LIN28 expression is also detectable in GCNIS, seminomas (including TCam-2) and ECs (Westetal. 2009, Nettersheim et al. 2011b). TCam-2 cells differentiate in vitro into a mixed nonseminoma upon stimulation with FGF4, EGF and TGF-b1 (Nettersheim et al. 2011b)
(Fig. 1A). During this process, LIN28A, but not LIN28B, and PRDM1 are downregulated, accompanied by reduced $\mathrm{H} 2 \mathrm{a} / \mathrm{H} 4 \mathrm{R} 3 m e 2 \mathrm{~s}$. Knocking down LIN28A in TCam-2 by siRNA suppresses PRDM1 expression, but reduction of PRDM1 leaves LIN28 unaffected (Nettersheim et al. 2011b). This suggests that in human PGCs, PRDM1 levels are fine-tuned by miR-let7, which in turn is suppressed by LIN28.

\section{DNA (de)methylation in GCs and GCTs}

PGCs undergo global DNA demethylation during migration, although running through several rounds of replication in the presence of DNMT1. Additionally, later during migration, they arrest in G2-phase. Thus, an active DNA demethylation process has been assumed (Hajkova et al. 2002, Saitou \& Yamaji 2012, Saitou et al. 2012). Hackett and coworkers demonstrated that this active DNA demethylation is driven by members of the Tet hydroxylase family (TET1/2) (Hackett et al. 2013). TET enzymes oxidize 5-methylcytosine (5mC) to 5-hydroxymethycytosine (5hmC), 5-formylcytosine (5fC) and 5-carboxylcytosine $(5 \mathrm{caC})$, resulting in activation of the base excision repair (BER) mechanism and in excision as well as replacement of a modified cytosine by an unmodified one (Hajkova et al. 2002, 2010). Expression of the TETS (1-3) and the co-keyplayer of active DNA demethylation TDG was detected in GCNIS, seminomas, ECs and corresponding cell lines (Nettersheim et al. 2013). In general, 5mC levels are low in GCNIS and seminomas, but high in non-seminomas (Smiraglia et al. 2002, Netto et al. 2008, Almstrup et al. 2010, Wermann et al. 2010). Nevertheless, the $5 \mathrm{mC}$ oxidation products $5 \mathrm{hmC}, 5 \mathrm{fC}$ and $5 \mathrm{caC}$ were detectable in all GCT cell lines analyzed and EC tissues (Nettersheim et al. 2013). In GCNIS and seminoma 
tissues, $5 \mathrm{hmC}$ correlated to the presence or absence of $5 \mathrm{mC}$ levels, while $5 \mathrm{fC}$ and $5 \mathrm{caC}$ were detectable in all GCNIS/seminoma samples independent of $5 \mathrm{mC} / 5 \mathrm{hmC}$ status (Nettersheim et al. 2013). In contrast to these data, Kristensen and coworkers found only very low levels of 5hmC and TET1 in GCNIS cells (Kristensen et al. 2014). Furthermore, they found high expression of APOBEC1, a key player of the deamination pathway of active DNA demethylation and of BER key players like MBD4, APEX1 and PARP (Branco et al. 2012, Kristensen et al. 2014). At the end of both pathways of active DNA demethylation, the oxidation and deamination pathway, the BER mechanism catalyzes replacement of a modified cytosine by an unmodified cytosine. Thus, expression of BER keyplayers in GCNIS/GCTs is consistent between published data, but future studies will show which (or if both) pathway(s) of active DNA demethylation is/are active in GCTs.

In adult human testis tissue, persisting $5 \mathrm{mC}$ marks were detected throughout all cell types of spermatogenesis, while $5 \mathrm{hmC}, 5 \mathrm{fC}$ and $5 \mathrm{caC}$ marks were detectable in spermatogonia, but steadily decreased with progression of spermatogenesis (Nettersheim et al. 2013). These findings point at an active DNA demethylation in spermatogonia, which is turned off upon initiation of spermatogenesis. The authors assume that $5 \mathrm{hmC}, 5 \mathrm{fC}$ and $5 \mathrm{caC}$ marks are diluted out with each round of mitosis/meiosis - similarly to a process already described during mouse preimplantation development (Inoue et al. 2011). Thus, the ability to actively demethylate DNA is maintained during maturation of PGCs to spermatogonia (but not further), development of GCTs and in GCT cell lines.

The pluripotency factor NANOG maintains selfrenewal of undifferentiated cells in concert with OCT3/4 and SOX2 (Chambers et al. 2003). Human spermatogonia (fetal and adult) as well as seminomas and TCam-2 cells display hypomethylation of the NANOG promoter $(0-10 \% 5 \mathrm{mC})$, which corresponds to high levels of NANOG expression (Nettersheim et al. 2011a). Hypomethylation of the Nanog promoter was also found in murine PGCs (Seisenberger et al. 2012). In murine testis tissue and sperm as well as in adult human testis tissue and mature sperm, the NANOG promoter is found hypermethylated ( $>60-100 \% 5 \mathrm{mC}$ ) (Imamura et al. 2006). At present, we can only speculate that, similar to the murine situation, human PGCs display hypomethylation of the NANOG promoter as well. Therefore, epigenetic silencing of NANOG expression via DNA methylation seems to occur at later stages of germ cell development. In line, expression of NANOG can be detected in human PGCs, but not in mature GCs (Kerr et al. 2008, Sugawa et al. 2015).

We speculate that in GCNIS cells, the methylation of the NANOG promoter fails to occur, keeping the gene locus open and accessible for transcription factors, thereby promoting pluripotency and self-renewal.
While failure to methylate (and silence expression) is clearly correlated to malignant aberration, in normal GCs downregulation of NANOG transcription clearly precedes the DNA methylation. Therefore, it seems that failure to methylate the NANOG promoter is not the cause of the malignancy, but rather the consequence.

\section{Screening for GC- and GCT-specific expression of noncoding RNAs}

Short noncoding RNAs (sncRNAs) like micro-RNAs (miRNAs) and PIWl-interacting RNAs (piRNAs) play important regulatory roles in many developmental processes, including germ cell development. De Jong and coworkers, Gillis and coworkers and Novotny and coworkers screened for the expression of miRNAs in GCNIS and invasive GCTs as well as fetal and adult testis tissue. In these studies, different groups of miRNAs that specifically distinguish among GCNIS, GCTs and (fetal, adult) testis tissue were identified (Gillis et al. 2007, de Jong et al. 2008, Novotny et al. 2012). For example, the miR146 is underexpressed in seminoma compared with normal testis tissue and putatively targets the PGC marker cKIT (He et al. 2005, Gillis et al. 2007). Furthermore, the embryonic germ cell-specific miRNA cluster 371-373 was upregulated in TCam-2 and GCT tissues, acting in conjunction with RAS downstream of P53. Additionally, miRNA cluster 302-367 is expressed in GCNIS, GCTs and fetal gonads (Gillis et al. 2007, Novotny et al. 2012). Novotny and coworkers conclude from these results that the miRNA expression profile changes during testis development and that the miRNA profile of adult testis with GCNIS cells shares characteristic similarities with the expression in fetal gonocytes (Novotny et al. 2012). Mclver and coworkers screened for changes in miRNA expression between postnatal gonocytes and spermatogonia to gain insight into the miRNA processes that influence maturation of gonocytes and might cause GCNIS development (Mclver et al. 2012). They found seven differentially expressed miRNAs (upregulated in spermatogonia vs gonocytes: miR136, -743q and -463; downregulated miR290-5p, -291a-5p, -293 and -294) that are involved in regulation of PTEN and WNT signaling and CyclinD1 (Mclver et al. 2012). The miRNA cluster 290-295 is highly expressed in ESCs and promotes proliferation and pluripotency by maintaining OCT3/4 expression (Zheng et al. 2011). Therefore, Mclver and coworkers believe that downregulation of miRNA cluster 290-295 marks initiation of gonocyte differentiation. Failure in downregulating this miRNA cluster might contribute to GCNIS formation (Mclver et al. 2012).

piRNAs are key players of genome integrity in the developing germ line as they inhibit the activity of transposable elements (Siomi et al. 2011). Ferreira and coworkers and Rounge and coworkers analyzed the 
expression of piRNAs and interacting PIWI proteins in GCTs compared with normal testis tissue. These studies revealed a strong downregulation of piRNAs in seminomatous and non-seminomatous GCTs (Ferreira et al. 2014, Rounge et al. 2015) and silencing of the PIWI genes PIWIL-1, -2 , and -4 by DNA methylation (Ferreira et al. 2014). Since PIWIL-2 is highly expressed in the fetal gonad and during early spermatogenesis to inhibit germline transposons like LINE-1 in concert with mature piRNAs, Ferreira and coworkers believe that the loss of the PIWI/piRNA machinery might play an important role in GCT development (Ferreira et al. 2014).

The alternative explanation is that the miRNA and piRNA profile detected in GCTs (persistence of expression of miRNAs from early gonocytes and lack to upregulate the piRNAs, which are indicative for germ cell differentiation) are yet another indicator for the arrested GC origin of GCTs as put forward by Skakkebaeck (Skakkebaek et al. 1987).

\section{The somatic microenvironment determines the fate of TCam-2 cells}

TCam-2 cells xenotransplanted orthotopically into the seminiferous tubules of nude mice grow GCNIS/ seminoma-like, while growth in a somatic microenvironment, like the flank or brain, promotes transition into an EC-like state (Nettersheim et al. 2012, 2013) (Fig. 1A). Additionally, cultivation of TCam-2 under culture conditions mimicking a somatic environment, forces differentiation into a mixed non-seminoma (Nettersheim et al. 2011b) (Fig. 1A). This transition of seminoma to an EC-like phenotype is accompanied by a number of epigenetic and molecular changes: the initial step in this process is the inhibition of BMP signaling by the microenvironment, resulting in de-repression of NODAL signaling (Nettersheim et al. 2015). During the so-called maturation phase, active NODAL signaling further represses intrinsic BMP signaling by activating $L E F T Y 1 / 2$, CRIPTO/CRYPTIC and ZIC3 (Nettersheim et al. 2015). This phase is accompanied by an overall increase in de novo DNA methylation and the upregulation of pluripotencyassociated genes (Nettersheim et al. 2015). Over time, a slow feedback loop re-establishes BMP signaling by activation of WNT3/5B, BMP4/BMP7 and FGF2/19, which stabilizes the acquired EC-like cell fate and results in a balance between NODAL and BMP signaling pathways (Nettersheim et al. 2015). SOX2 is essential for initiation of the NODAL signaling loop during this reprogramming. Lack of SOX2 results in failure to activate the NODAL signaling key-players $L E F T Y 1 / 2$ and CRIPTO, suggesting that SOX2 is downstream of BMP inhibition but upstream of NODAL activation (Nettersheim et al. 2016).

This demonstrates that the cellular microenvironment has a profound impact on the cell fate of TCam-2 cells. Since it was demonstrated that TCam-2 closely resemble PGCs (Irie et al. 2015, Tang et al. 2015), we speculate that proper PGC development also depends on a crosstalk with the somatic cells from the gonadal microenvironment, i.e. BMP signaling regulating NODAL activity. Factors leading to alterations of this crosstalk might interfere with the tightly controlled repression of pluripotency factors. In this context, the roles of endocrine disruptors might also be important.

\section{Endocrine disruptors as a risk factor for GCT development and testicular dysgenesis syndrome}

In Western countries, human sperm count is steadily declining, while the incidence of testicular dysgenesis syndrome (TDS), involving testicular cancer, cryptorchidism and hypospadias, is rising both indications might be explained by the exposure to hormonally active substances found in our environment (Jensen et al. 1995, Nilsson 2000, Skakkebaek et al. 2001, Nohynek et al. 2013, Hauser et al. 2015). Endocrine disruptors (EDs), i.e. phthalates, polychlorinated biphenyls or alkylphenols are small molecules acting like hormones, which can cause adverse health effects (toxicity) via endocrine-mediated mechanisms (Nohynek et al. 2013). Several studies suggest their negative influence on reproduction by mimicking/modulating of sex hormones that are secreted by the ovaries or testes (Nilsson 2000). As reviewed by Del-Mazo and coworkers, EDs may adversely affect gene expression levels in PGCs and developing testis (i.e. oxidative stress response) or epigenetic processes in sperm (i.e. by deregulation of epigenetic enzymes) (Wu et al. 2010, Del-Mazo et al. 2013). Therefore, exposure of PGCs to EDs may interfere with the downregulation of the PGC- and pluripotency program, leading to increased development of GCNIS or type I GCTs.

Further, Ohlson and coworkers demonstrated a sixfold increased risk for developing seminomas among men exposed to polyvinyl chloride (PVC), the third-most commonly used plastic polymer in the environment (Ohlson \& Hardell 2000).

So, it seems that exposure to EDs in utero could lead to increased rate of PGCs transformed to GCNIS cells, which in adulthood are further triggered by e.g. PVC to progress into a GCT. In this respect, in vitro studies using GCT cell lines, especially TCam-2 could help to get insights into the effects of EDs on gene expression, protein composition and epigenetics of GCs (Del-Mazo et al. 2013).

\section{Does poised chromatin render germ cells prone to transformation?}

According to the theory first described by Skakkebaek, a PGC/gonocyte has failed to differentiate further and remains silent until puberty, where it starts to proliferate 
giving rise to GCNIS and subsequently seminomas or non-seminomas (Skakkebaek 1972, Skakkebaek et al. 1987). Molecular analyses of the past decades in part reviewed here further substantiated this claim.

Recently, several groups found that through the germ line, a very characteristic pattern of histone modifications, the presence of repressive marks (H3K27me3) and active marks (H3K4me3) is detected at key developmental promoters (Hammoud et al. 2009, Sachs et al. 2013, Lesch \& Page 2014). This so-called 'poised' chromatin is also detected in pluripotent ESCs and thought to be instrumental for pluripotency (Azuara et al. 2006, Bernstein et al. 2006, Mikkelsen et al. 2007). As a consequence, the mammalian germ line has been described as a pluripotency cycle featuring an epigenetic status, which is primed to rapidly re-activate toti- and pluripotency upon fertilization (Leitch \& Smith 2013).

In light of these findings, we would like to extend the hypothesis of the origin of type II GCTs from Skakkebaek (Fig. 1A). While several lines of evidence indicate that a germ cell tumor originates from a 'misinstructed' PGC or early gonocyte, we propose that germline cells from adult mice and humans, which have not initiated meiosis, are also able to give rise to a type II GCT, because these cells are epigenetically prepared to rapidly re-activate totipotency. Therefore, exposure to EDs interfering with the mechanisms and stabilizing this poised state might lead to re-initiation of the pluripotency program, resulting in the formation of a GCNIS or a type I GCT. In fact, stochastic re-activation of the pluripotency program has been demonstrated for gonadal cells from adult mice and humans. They convert to induced pluripotent cells solely by application of appropriate media conditions (Kanatsu-Shinohara et al. 2008, Ko et al. 2009, Kossack et al. 2009, Liu et al. 2011). Therefore, it seems that germ cells harboring 'poised' histone marks in conjunction with reduced DNA methylation are more than other somatic cells at risk to re-activate the PGC and pluripotency program and, as such, initiate the formation of GCTs.

\section{Declaration of interest}

The authors declare that there is no conflict of interest that could be perceived as prejudicing the impartiality of the research reported.

\section{Funding}

This work was supported by DFG to H S (Scho503/16-1).

\section{References}

Aggarwal N \& Parwani AV 2009 Spermatocytic seminoma. Archives of Pathology \& Laboratory Medicine 133 1985-1988.

Almstrup K, Hoei-Hansen CE, Nielsen JE, Wirkner U, Ansorge W, Skakkebaek NE, Rajpert-De Meyts E \& Leffers H 2005 Genome-wide gene expression profiling of testicular carcinoma in situ progression into overt tumours. British Journal of Cancer 92 1934-1941. (doi:10.1038/ sj.bjc.6602560)

Almstrup K, Nielsen JE, Mlynarska O, Jansen MT, Jørgensen A, Skakkebæk N \& Meyts ER-D 2010 Carcinoma in situ testis displays permissive chromatin modifications similar to immature foetal germ cells. British Journal of Cancer 103 1-8. (doi:10.1038/sj.bjc.6605682)

Ancelin K, Lange UC, Hajkova P, Schneider R, Bannister AJ, Kouzarides T \& Surani MA 2006 Blimp1 associates with Prmt5 and directs histone arginine methylation in mouse germ cells. Nature Cell Biology 8 623-630. (doi:10.1038/ncb1413)

Andrews PW 1982 Human embryonal carcinoma cells in culture do not synthesize fibronectin until they differentiate. International Journal of Cancer 30 567-571. (doi:10.1002/(ISSN)1097-0215)

Andrews PW, Damjanov I, Simon D, Banting GS, Carlin C, Dracopoli NC \& Føgh J 1984 Pluripotent embryonal carcinoma clones derived from the human teratocarcinoma cell line Tera-2. Differentiation in vivo and in vitro. Laboratory Investigation 50 147-162.

Ara T, Nakamura Y, Egawa T, Sugiyama T, Abe K, Kishimoto T, Matsui Y \& Nagasawa T 2003 Impaired colonization of the gonads by primordial germ cells in mice lacking a chemokine, stromal cell-derived factor-1 (SDF-1). PNAS 100 5319-5323. (doi:10.1073/pnas.0730719100)

Azuara V, Perry P, Sauer S, Spivakov M, Jørgensen HF, John RM, Gouti M, Casanova M, Warnes G, Merkenschlager M et al. 2006 Chromatin signatures of pluripotent cell lines. Nature Cell Biology 8 532-538. (doi:10.1038/ncb1403)

Balhorn R 2007 The protamine family of sperm nuclear proteins. Genome Biology 8 227-227. (doi:10.1186/gb-2007-8-9-227)

Bassetto MA, Pasini F, Franceschi T, Mustacchi G \& Cetto GL 1995 Extragonadal germ cell tumor: a clinical study. Anticancer Research 15 2751-2754.

Berney DM, Looijenga L, Idrees M, Oosterhuis JW, Rajpert-De Meyts E, Ulbright TM \& Skakkebaek NE 2016 Germ cell neoplasia in situ (GCNIS): evolution of the current nomenclature for testicular preinvasive germ cell malignancy. Histopathology 69 7-10. (doi:10.1111/ his.2016.69.issue-1)

Bernstein BE, Mikkelsen TS, Xie X, Kamal M, Huebert DJ, Cuff J, Fry B, Meissner A, Wernig M, Plath K et al. 2006 A bivalent chromatin structure marks key developmental genes in embryonic stem cells. Cell 125 315-326. (doi:10.1016/j.cell.2006.02.041)

Biermann K, Goke F, Nettersheim D, Eckert D, Zhou H, Kahl P, Gashaw I, Schorle H \& Buttner R 2007 C-KIT is frequently mutated in bilateral germ cell tumours and down-regulated during progression from intratubular germ cell neoplasia to seminoma. Journal of Pathology 213 311-318. (doi:10.1002/(ISSN)1096-9896)

Bowles J \& Koopman P 2007 Retinoic acid, meiosis and germ cell fate in mammals. Development 134 3401-3411. (doi:10.1242/dev.001107)

Branco MR, Ficz G \& Reik W 2012 Uncovering the role of 5-hydroxymethylcytosine in the epigenome. Nature Reviews Genetics 13 1-7. (doi:10.1038/nrg3080)

Bronson DL, Andrews PW, Solter D, Cervenka J, Lange PH \& Fraley EE 1980 Cell line derived from a metastasis of a human testicular germ cell tumor. Cancer Research 40 2500-2506.

Bronson DL, Andrews PW, Vessella RL \& Fraley EE 1983 In vitro differentiation of human embryonal carcinoma cells. In Teratocarcinoma Stem Cells. Cold Spring Harbour Conferences on Cell Proliferation, vol 10, pp 597-605. Eds LM Silver, GR Martin \& S Strickland. Cold Spring Harbor, NY, USA: Cold Spring Harbor Laboratory.

Campolo F, Gori M, Favaro R, Nicolis S, Pellegrini M, Botti F, Rossi P, Jannini EA \& Dolci S 2013 Essential role of Sox2 for the establishment and maintenance of the germ cell line. Stem Cells 31 1408-1421. (doi:10.1002/stem.v31.7)

Casper J, Schmoll HJ, Schnaidt U \& Fonatsch C 1987 Cell lines of human germinal cancer. International Journal of Andrology 10 105-113. (doi:10.1111/j.1365-2605.1987.tb00171.x)

Chaerkady R, Kerr CL, Kandasamy K, Marimuthu A, Gearhart JD \& Pandey A 2010 Comparative proteomics of human embryonic stem cells and embryonal carcinoma cells. Proteomics 10 1359-1373. (doi:10.1002/pmic.200900483)

Chambers I, Colby D, Robertson M, Nichols J, Lee S, Tweedie S \& Smith A 2003 Functional expression cloning of Nanog, a pluripotency sustaining factor in embryonic stem cells. Cell 113 643-655. (doi:10.1016/S00928674(03)00392-1) 
Clermont Y 1966 Renewal of spermatogonia in man. American Journal of Anatomy 118 509-524. (doi:10.1002/(ISSN)1553-0795)

Damjanov I, Horvat B \& Gibas Z 1993 Retinoic acid-induced differentiation of the developmentally pluripotent human germ cell tumor-derived cell line, NCCIT. Laboratory Investigation 68 220-232.

de Jong J, Stoop H, Gillis AJ, Van Gurp RJ, van de Geijn GJ, Boer M, Hersmus R, Saunders PT, Anderson RA, Oosterhuis JW et al. 2008 Differential expression of SOX17 and SOX2 in germ cells and stem cells has biological and clinical implications. Journal of Pathology 215 21-30. (doi:10.1002/(ISSN)1096-9896)

de Rooij DG 2001 Proliferation and differentiation of spermatogonial stem cells. Reproduction 121 347-354. (doi:10.1530/rep.0.1210347)

Del-Mazo J, Brieño-Enríquez MA, García-López J, López-Fernández LA \& De Felici M 2013 Endocrine disruptors, gene deregulation and male germ cell tumors. International Journal of Developmental Biology 57 225-239. (doi:10.1387/ijdb.130042jd)

Eckert D, Biermann K, Nettersheim D, Gillis AJ, Steger K, Jack HM, Muller AM, Looijenga LH \& Schorle H 2008 Expression of BLIMP1/ PRMT5 and concurrent histone $\mathrm{H} 2 \mathrm{~A} / \mathrm{H} 4$ arginine 3 dimethylation in fetal germ cells, CIS/IGCNU and germ cell tumors. BMC Developmental Biology 8 106. (doi:10.1186/1471-213X-8-106)

Ezeh UI, Turek PJ, Reijo RA \& Clark AT 2005 Human embryonic stem cell genes OCT4, NANOG, STELLAR, and GDF3 are expressed in both seminoma and breast carcinoma. Cancer 104 2255-2265. (doi:10.1002/ (ISSN)1097-0142)

Ferreira HJ, Heyn H, Garcia del Muro X, Vidal A, Larriba S, Muñoz C, Villanueva A \& Esteller M 2014 Epigenetic loss of the PIWI/piRNA machinery in human testicular tumorigenesis. Epigenetics 9 113-118. (doi:10.4161/epi.27237)

Gilbert DC, Chandler I, McIntyre A, Goddard NC, Gabe R, Huddart RA \& Shipley J 2009 Clinical and biological significance of CXCL12 and CXCR4 expression in adult testes and germ cell tumours of adults and adolescents. Journal of Pathology 217 94-102. (doi:10.1002/path.v217:1)

Gill ME, Hu Y-C, Lin Y \& Page DC 2011 Licensing of gametogenesis, dependent on RNA binding protein DAZL, as a gateway to sexual differentiation of fetal germ cells. PNAS 108 7443-7448. (doi:10.1073/ pnas.1104501108)

Gillis AJM, Stoop HJ, Hersmus R, Oosterhuis JW, Sun Y, Chen C, Guenther S, Sherlock J, Veltman I, Baeten J et al. 2007 High-throughput microRNAome analysis in human germ cell tumours. Journal of Pathology 213 319-328. (doi:10.1002/path.v213:3)

Giwercman A \& Skakkebaek NE 1993 Carcinoma in situ of the testis: biology, screening and management. European Urology 23 (Supplement 2) 19-21.

Goriely A, Hansen RMS, Taylor IB, Olesen IA, Jacobsen GK, McGowan SJ, Pfeifer SP, McVean GAT, Rajpert De-Meyts E \& Wilkie AOM 2009 Activating mutations in FGFR3 and HRAS reveal a shared genetic origin for congenital disorders and testicular tumors. Nature Genetics $\mathbf{4 1}$ 1247-1252. (doi:10.1038/ng.470)

Gu Y, Runyan C, Shoemaker A, Surani A \& Wylie C 2009 Steel factor controls primordial germ cell survival and motility from the time of their specification in the allantois, and provides a continuous niche throughout their migration. Development 136 1295-1303. (doi:10.1242/dev.030619)

Guan G, Zhang Y, Lu Y, Liu L, Shi D, Wen Y, Yang L, Ma Q, Liu T, Zhu X et al. 2015 The HIF- $1 \alpha /$ CXCR4 pathway supports hypoxia-induced metastasis of human osteosarcoma cells. Cancer Letters 357 254-264. (doi:10.1016/j.canlet.2014.11.034)

Hackett JA, Sengupta R, Zylicz JJ, Murakami K, Lee C, Down TA \& Surani MA 2013 Germline DNA demethylation dynamics and imprint erasure through 5-hydroxymethylcytosine. Science 339 448-452. (doi:10.1126/science.1229277)

Hajkova P, Erhardt S, Lane N, Haaf T, El-Maarri O, Reik W, Walter J \& Surani MA 2002 Epigenetic reprogramming in mouse primordial germ cells. Mechanisms of Development 117 15-23. (doi:10.1016/S09254773(02)00181-8)

Hajkova P, Jeffries SJ, Lee C, Miller N, Jackson SP \& Surani MA 2010 Genome-wide reprogramming in the mouse germ line entails the base excision repair pathway. Science 329 78-82. (doi:10.1126/ science.1187945)

Hammoud SS, Nix DA, Zhang H, Purwar J, Carrell DT \& Cairns BR 2009 Distinctive chromatin in human sperm packages genes for embryo development. Nature 460 473-478. (doi:10.1038/nature08162)
Hauser R, Skakkebaek NE, Hass U, Toppari J, Juul A, Andersson AM, Kortenkamp A, Heindel JJ \& Trasande L 2015 Male reproductive disorders, diseases, and costs of exposure to endocrine-disrupting chemicals in the European union. Journal of Clinical Endocrinology and Metabolism 100 1267-1277. (doi:10.1210/jc.2014-4325)

Hayashi K, de Sousa Lopes SMC \& Surani MA 2007 Germ cell specification in mice. Science 316 394-396. (doi:10.1126/science.1137545)

He H, Jazdzewski K, Li W, Liyanarachchi S, Nagy R, Volinia S, Calin GA, Liu C-G, Franssila K, Suster S et al. 2005 The role of microRNA genes in papillary thyroid carcinoma. PNAS 102 19075-19080. (doi:10.1073/ pnas.0509603102)

Hochberg A, Rachmilewitz J, Eldar-Geva T, Salant T, Schneider T \& de Groot N 1992 Differentiation of choriocarcinoma cell line (JAr). Cancer Research 52 3713-3717.

Hoei-Hansen CE, Nielsen JE, Almstrup K, Sonne SB, Graem N, Skakkebaek NE, Leffers H \& Rajpert De-Meyts E 2004 Transcription factor AP-2gamma is a developmentally regulated marker of testicular carcinoma in situ and germ cell tumors. Clinical Cancer Research 10 8521-8530. (doi:10.1158/1078-0432.CCR-04-1285)

Hoei-Hansen CE, Rajpert-De Meyts E, Daugaard G \& Skakkebaek NE 2005 Carcinoma in situ testis, the progenitor of testicular germ cell tumours: a clinical review. Annals of Oncology 16 863-868. (doi:10.1093/annonc/ mdi175)

Hogan B, Fellous M, Jacob F \& Avner P 1977 Isolation of a human teratoma cell line which expresses F9 antigen. Nature 270 515-518. (doi:10.1038/270515a0)

Houldsworth J, Reuter V, BosI GJ \& Chaganti RS 1997 Aberrant expression of cyclin D2 is an early event in human male germ cell tumorigenesis. Cell Growth \& Differentiation: The Molecular Biology Journal of the American Association for Cancer Research 8 293-299.

Imamura M, Miura K, Iwabuchi K, Ichisaka T, Nakagawa M, Lee J, Kanatsu-Shinohara M, Shinohara T \& Yamanaka S 2006 Transcriptional repression and DNA hypermethylation of a small set of ES cell marker genes in male germline stem cells. BMC Developmental Biology 634 . (doi:10.1186/1471-213X-6-34)

Inoue A, Shen L, Dai Q, He C \& Zhang Y 2011 Generation and replicationdependent dilution of $5 \mathrm{fC}$ and $5 \mathrm{caC}$ during mouse preimplantation development. Cell Research 21 1670-1676. (doi:10.1038/cr.2011.189)

Irie N, Weinberger L, Tang WWC, Kobayashi T, Viukov S, Manor YS, Dietmann S, Hanna JH \& Surani MA 2015 SOX17 Is a critical specifier of human primordial germ cell fate. Cell 160 253-268. (doi:10.1016/j. cell.2014.12.013)

Jameson SA, Natarajan A, Cool J, DeFalco T, Maatouk DM, Mork L, Munger SC \& Capel B 2012 Temporal transcriptional profiling of somatic and germ cells reveals biased lineage priming of sexual fate in the fetal mouse gonad. PLOS Genetics 8 e1002575. (doi:10.1371/journal. pgen.1002575)

Jensen TK, Toppari J, Keiding N \& Skakkebaek NE 1995 Do environmental estrogens contribute to the decline in male reproductive health? Clinical Chemistry 41 1896-1901.

Johnson DE, Appelt G, Samuels ML \& Luna M 1976 Metastases from testicular carcinoma. Study of 78 autopsied cases. Urology 8 234-239. (doi:10.1016/0090-4295(76)90374-5)

Kamakura Y, Hasegawa M, Minamoto T, Yamashita J \& Fujisawa H 2006 C-kit gene mutation: common and widely distributed in intracranial germinomas. Journal of Neurosurgery 104 173-180. (doi:10.3171/ ped.2006.104.3.173)

Kanatsu-Shinohara M, Lee J, Inoue K, Ogonuki N, Miki H, Toyokuni S, Ikawa M, Nakamura T, Ogura A \& Shinohara T 2008 Pluripotency of a single spermatogonial stem cell in mice. Biology of Reproduction $\mathbf{7 8}$ 681-687. (doi:10.1095/biolreprod.107.066068)

Kashimada K \& Koopman P 2010 Sry: the master switch in mammalian sex determination. Development 137 3921-3930. (doi:10.1242/ dev.048983)

Kehler J, Tolkunova E, Koschorz B, Pesce M, Gentile L, Boiani M, Lomelí H, Nagy A, McLaughlin KJ, Scholer HR et al. 2004 Oct4 is required for primordial germ cell survival. EMBO Reports 5 1078-1083. (doi:10.1038/sj.embor.7400279)

Kemmer K, Corless CL, Fletcher JA, McGreevey L, Haley A, Griffith D, Cummings OW, Wait C, Town A \& Heinrich MC 2004 KIT mutations are common in testicular seminomas. American Journal of Pathology 164 305-313. (doi:10.1016/S0002-9440(10)63120-3) 
Kerr CL, Hill CM, Blumenthal PD \& Gearhart JD 2008 Expression of pluripotent stem cell markers in the human fetal testis. Stem Cells 26 412-421. (doi:10.1634/stemcells.2007-0605)

Kinugawa K, Hyodo F, Matsuki T, Jo Y, Furukawa Y, Ueki A \& Tanaka H 1998 Establishment and characterization of a new human testicular seminoma cell line, JKT-1. International Journal of Urology 5 282-287. (doi:10.1111/iju.1998.5.issue-3)

Ko K, Tapia N, Wu G, Kim JB, Bravo MJA, Sasse P, Glaser T, Ruau D, Han DW, Greber B et al. 2009 Induction of pluripotency in adult unipotent germline stem cells. Cell Stem Cell 5 87-96. (doi:10.1016/j. stem.2009.05.025)

Kohler PO \& Bridson WE 1971 Isolation of hormone-producing clonal lines of human choriocarcinoma. Journal of Clinical Endocrinology and Metabolism 32 683-687. (doi:10.1210/jcem-32-5-683)

Kossack N, Meneses J, Shefi S, Nguyen HN, Chavez S, Nicholas C, Gromoll J, Turek PJ \& Reijo-Pera RA 2009 Isolation and characterization of pluripotent human spermatogonial stem cell-derived cells. Stem Cells 27 138-149. (doi:10.1634/stemcells.2008-0439)

Koubova J, Menke DB, Zhou Q, Capel B, Griswold MD \& Page DC 2006 Retinoic acid regulates sex-specific timing of meiotic initiation in mice. PNAS 103 2474-2479. (doi:10.1073/pnas.0510813103)

Krentz AD, Murphy MW, Zhang T, Sarver AL, Jain S, Griswold MD, Bardwell VJ \& Zarkower D 2013 Interaction between DMRT1 function and genetic background modulates signaling and pluripotency to control tumor susceptibility in the fetal germ line. Developmental Biology 377 67-78. (doi:10.1016/j.ydbio.2013.02.014)

Kristensen DG, Nielsen JE, Jorgensen A, Skakkebaek NE, RajpertDe Meyts E \& Almstrup K 2014 Evidence that active demethylation mechanisms maintain the genome of carcinoma in situ cells hypomethylated in the adult testis. British Journal of Cancer $\mathbf{1 1 0}$ 668-678. (doi:10.1038/bjc.2013.727)

Kumar S, Chatzi C, Brade T, Cunningham TJ, Zhao X \& Duester G 2011 Sex-specific timing of meiotic initiation is regulated by Cyp26b1 independent of retinoic acid signalling. Nature Communications 2 151-158. (doi:10.1038/ncomms1136)

Leitch HG \& Smith A 2013 The mammalian germline as a pluripotency cycle. Development 140 2495-2501. (doi:10.1242/dev.091603)

Leroy X, Augusto D, Leteurtre E \& Gosselin B 2002 CD30 and CD117 (c-kit) used in combination are useful for distinguishing embryonal carcinoma from seminoma. Journal of Histochemistry and Cytochemistry $\mathbf{5 0}$ 283-285. (doi:10.1177/002215540205000216)

Lesch BJ \& Page DC 2014 Poised chromatin in the mammalian germ line. Development 141 3619-3626. (doi:10.1242/dev.113027)

Lin Y \& Page DC 2005 Dazl deficiency leads to embryonic arrest of germ cell development in XY C57BL/6 mice. Developmental Biology 288 309-316. (doi:10.1016/j.ydbio.2005.06.032)

Lin Y, Gill ME, Koubova J \& Page DC 2008 Germ cell-intrinsic and -extrinsic factors govern meiotic initiation in mouse embryos. Science 322 1685-1687. (doi:10.1126/science.1166340)

Liu S, Tang Z, Xiong T \& Tang W 2011 Isolation and characterization of human spermatogonial stem cells. Reproductive Biology and Endocrinology: RB\&E 9 141. (doi:10.1186/1477-7827-9-141)

Looijenga LH \& Oosterhuis JW 1999 Pathogenesis of testicular germ cell tumours. Reviews of Reproduction 4 90-100. (doi:10.1530/ ror.0.0040090)

Luk JM, Lee NPY, Shum CK, Lam BY, Siu AFM, Che C-M, Tam P-C, Cheung ANY, Yang ZM, Lin Y-N et al. 2006 Acrosome-specific gene AEP1: identification, characterization and roles in spermatogenesis. Journal of Cellular Physiology 209 755-766. (doi:10.1002/jcp.v209:3)

Ma N, Pang H, Shen W, Zhang F, Cui Z, Wang J, Wang J, Liu L \& Zhang H 2015 Downregulation of CXCR4 by SDF-KDEL in SBC-5 cells inhibits their migration in vitro and organ metastasis in vivo. International Journal of Molecular Medicine 35 425-432. (doi:10.3892/ ijmm.2014.2033)

Mclver SC, Stanger SJ, Santarelli DM, Roman SD, Nixon B \& McLaughlin EA 2012 A unique combination of male germ cell miRNAs coordinates gonocyte differentiation. PLOS ONE 7 e35553. (doi:10.1371/journal. pone.0035553)

Meyenn von F \& Reik W 2015 Forget the parents: epigenetic reprogramming in human germ cells. Cell 161 1248-1251. (doi:10.1016/j.cell. 2015.05.039)

Mikkelsen TS, Ku M, Jaffe DB, Issac B, Lieberman E, Giannoukos G, Alvarez P, Brockman W, Kim T-K, Koche RP et al. 2007 Genome-wide maps of chromatin state in pluripotent and lineage-committed cells. Nature 448 553-560. (doi:10.1038/nature06008)

Mizuno Y, Gotoh A, Kamidono S \& Kitazawa S 1993 [Establishment and characterization of a new human testicular germ cell tumor cell line (TCam-2)]. Nippon Hinyokika Gakkai Zasshi 84 1211-1218.

Molyneaux KA, Zinszner H, Kunwar PS, Schaible K, Stebler J, Sunshine MJ, O'Brien W, Raz E, Littman D, Wylie C et al. 2003 The chemokine SDF1/ CXCL12 and its receptor CXCR4 regulate mouse germ cell migration and survival. Development 130 4279-4286. (doi:10.1242/dev.00640)

Nakaki F, Hayashi K, Ohta H, Kurimoto K, Yabuta Y \& Saitou M 2013 Induction of mouse germ-cell fate by transcription factors in vitro. Nature 501 222-226. (doi:10.1038/nature12417)

Nettersheim D, Biermann K, Gillis AJ, Steger K, Looijenga LH \& Schorle H 2011a NANOG promoter methylation and expression correlation during normal and malignant human germ cell development. Epigenetics 6 114-122. (doi:10.4161/epi.6.1.13433)

Nettersheim D, Gillis AJ, Looijenga LH \& Schorle H 2011b TGF-beta1, EGF and FGF4 synergistically induce differentiation of the seminoma cell line TCam-2 into a cell type resembling mixed non-seminoma. International Journal of Andrology 34 e189-e203. (doi:10.1111/j.13652605.2011.01172.x)

Nettersheim D, Westernströer B, Haas N, Leinhaas A, Brüstle O, Schlatt S \& Schorle H 2012 Establishment of a versatile seminoma model indicates cellular plasticity of germ cell tumor cells. Genes, Chromosomes and Cancer 51 717-726. (doi:10.1002/gcc.v51.7)

Nettersheim D, Heukamp LC, Fronhoffs F, Grewe MJ, Haas N, Waha A, Honecker F, Waha A, Kristiansen G \& Schorle H 2013 Analysis of TET expression/activity and $5 \mathrm{mC}$ oxidation during normal and malignant germ cell development. PLOS ONE 8 e82881. (doi:10.1371/journal. pone.0082881)

Nettersheim D, Jostes S, Sharma R, Schneider S, Hofmann A, Ferreira HJ, Hoffmann P, Kristiansen G, Esteller MB \& Schorle H 2015 BMP inhibition in seminomas initiates acquisition of pluripotency via NODAL signaling resulting in reprogramming to an embryonal carcinoma. PLOS Genetics 11 e1005415. (doi:10.1371/journal.pgen.1005415)

Nettersheim D, Heimsoeth A, Jostes S, Schneider S, Fellermeyer M, Hofmann A \& Schorle H 2016 SOX2 is essential for in vivo reprogramming of seminoma-like TCam-2 cells to an embryonal carcinoma-like fate. Oncotarget 7 47095-47110. (doi:10.18632/oncotarget.9903)

Netto GJ, Nakai Y, Nakayama M, Jadallah S, Toubaji A, Nonomura N, Albadine R, Hicks JL, Epstein J, Yegnasubramanian S et al. 2008 Global DNA hypomethylation in intratubular germ cell neoplasia and seminoma, but not in nonseminomatous male germ cell tumors. Modern Pathology 21 1337-1344. (doi:10.1038/ modpathol.2008.127)

Newman MA, Thomson JM \& Hammond SM 2008 Lin-28 interaction with the Let-7 precursor loop mediates regulated microRNA processing. RNA 14 1539-1549. (doi:10.1261/rna.1155108)

Nilsson R 2000 Endocrine modulators in the food chain and environment. Toxicologic Pathology 28 420-431. (doi:10.1177/019262330002800311)

Nohynek GJ, Borgert CJ, Dietrich D \& Rozman KK 2013 Endocrine disruption: fact or urban legend? Toxicology Letters 223 295-305. (doi:10.1016/j.toxlet.2013.10.022)

Novotny GW, Belling KC, Bramsen JB, Nielsen JE, Bork-Jensen J, Almstrup K, Sonne SB, Kjems J, Rajpert De-Meyts E \& Leffers H 2012 MicroRNA expression profiling of carcinoma in situ cells of the testis. Endocrine-Related Cancer 19 365-379. (doi:10.1530/ERC-11-0271)

Ohinata Y, Payer B, O'Carroll D, Ancelin K, Ono Y, Sano M, Barton SC, Obukhanych T, Nussenzweig M, Tarakhovsky A et al. 2005 Blimp1 is a critical determinant of the germ cell lineage in mice. Nature 436 207-213. (doi:10.1038/nature03813)

Ohlson CG \& Hardell L 2000 Testicular cancer and occupational exposures with a focus on xenoestrogens in polyvinyl chloride plastics. Chemosphere 40 1277-1282. (doi:10.1016/S0045-6535(99)00380-X)

Oosterhuis JW \& Looijenga LH 2005 Testicular germ-cell tumours in a broader perspective. Nature Reviews Cancer 5 210-222. (doi:10.1038/ nrc1568)

Ottesen AM, Skakkebaek NE, Lundsteen C, Leffers H, Larsen J \& Rajpert De-Meyts E 2003 High-resolution comparative genomic hybridization detects extra chromosome arm 12p material in most cases of carcinoma in situ adjacent to overt germ cell tumors, but not before the invasive tumor development. Genes, Chromosomes and Cancer 38 117-125. (doi:10.1002/gcc.v38:2) 
Pattillo RA \& Gey GO 1968 The establishment of a cell line of human hormone-synthesizing trophoblastic cells in vitro. Cancer Research $\mathbf{2 8}$ 1231-1236.

Pera MF, Blasco Lafita MJ \& Mills J 1987 Cultured stem-cells from human testicular teratomas: the nature of human embryonal carcinoma, and its comparison with two types of yolk-sac carcinoma. International Journal of Cancer 40 334-343. (doi:10.1002/(ISSN)1097-0215)

Pera MF, Reubinoff B \& Trounson A 2000 Human embryonic stem cells. Journal of Cell Science 113 5-10.

Perrett RM, Turnpenny L, Eckert JJ, O'Shea M, Sonne SB, Cameron IT, Wilson DI, Rajpert De-Meyts E \& Hanley NA 2008 The early human germ cell lineage does not express SOX2 during in vivo development or upon in vitro culture. Biology of Reproduction 78 852-858. (doi:10.1095/biolreprod.107.066175)

Pirouz M, Klimke A \& Kessel M 2012 The reciprocal relationship between primordial germ cells and pluripotent stem cells. Journal of Molecular Medicine 90 753-761. (doi:10.1007/s00109-012-0912-1)

Przygodzki RM, Hubbs AE, Zhao F-Q \& O'Leary TJ 2002 Primary mediastinal seminomas: evidence of single and multiple KIT mutations. Laboratory Investigation 82 1369-1375. (doi:10.1097/01. LAB.0000032410.46986.7B)

Raiss GG, Andaloussi MMB, Raissouni SS, Mrabti HH \& Errihani $\mathbf{H H}$ 2011 Spermatocytic seminoma at the National Institute of Oncology in Morocco. BMC Research Notes 4 218. (doi:10.1186/1756-0500-4-218)

Rajpert-De Meyts E \& Skakkebaek NE 1994 Expression of the c-kit protein product in carcinoma-in-situ and invasive testicular germ cell tumours. International Journal of Andrology 17 85-92. (doi:10.1111/j.1365-2605.1994.tb01225.x)

Reuter VE 2005 Origins and molecular biology of testicular germ cell tumors. Modern Pathology 18 (Supplement 2) S51-S60. (doi:10.1038/ modpathol.3800309)

Rosenberg C, Mostert MC, Schut TB, van de Pol M, van Echten J, de Jong B, Raap AK, Tanke H, Oosterhuis JW \& Looijenga LH 1998 Chromosomal constitution of human spermatocytic seminomas: comparative genomic hybridization supported by conventional and interphase cytogenetics. Genes, Chromosomes and Cancer 23 286-291. (doi:10.1002/ (ISSN)1098-2264)

Rosenberg C, Van Gurp RJ, Geelen E, Oosterhuis JW \& Looijenga LH 2000 Overrepresentation of the short arm of chromosome 12 is related to invasive growth of human testicular seminomas and nonseminomas. Oncogene 19 5858-5862. (doi:10.1038/sj.onc.1203950)

Rounge TB, Furu K, Skotheim RI, Haugen TB, Grotmol T \& Enerly E 2015 Profiling of the small RNA populations in human testicular germ cell tumors shows global loss of piRNAs. Molecular Cancer 14153. (doi:10.1186/s12943-015-0411-4)

Runyan C, Schaible K, Molyneaux K, Wang Z, Levin L \& Wylie C 2006 Steel factor controls midline cell death of primordial germ cells and is essential for their normal proliferation and migration. Development 133 4861-4869. (doi:10.1242/dev.02688)

Russell SM, Lechner MG, Mokashi A, Megiel C, Jang JK, Taylor CR, Looijenga LHJ, French CA \& Epstein AL 2013 Establishment and characterization of a new human extragonadal germ cell line, SEM-1, and its comparison with TCam-2 and JKT-1. Urology 81 464.e1-464.e9. (doi:10.1016/j.urology.2012.09.029)

Sachs M, Onodera C, Blaschke K, Ebata KT, Song JS \& Ramalho-Santos M 2013 Bivalent chromatin marks developmental regulatory genes in the mouse embryonic germline in vivo. Cell Reports 3 1777-1784. (doi:10.1016/j.celrep.2013.04.032)

Saitou M \& Yamaji M 2012 Primordial germ cells in mice. Cold Spring Harbor Perspectives in Biology 4 a008375-a008375. (doi:10.1101/ cshperspect.a008375)

Saitou M, Kagiwada S \& Kurimoto K 2012 Epigenetic reprogramming in mouse pre-implantation development and primordial germ cells. Development 139 15-31. (doi:10.1242/dev.050849)

Sakuma Y, Sakurai S, Oguni S, Hironaka M \& Saito K 2003 Alterations of the c-kit gene in testicular germ cell tumors. Cancer Science $\mathbf{9 4}$ 486-491. (doi:10.1111/cas.2003.94.issue-6)

Sakuma Y, Sakurai S, Oguni S, Satoh M, Hironaka M \& Saito K 2004 c-kit gene mutations in intracranial germinomas. Cancer Science $\mathbf{9 5}$ 716-720. (doi:10.1111/cas.2004.95.issue-9)

Schemmer J, Araúzo-Bravo MJ, Haas N, Schäfer S, Weber SN, Becker A, Eckert D, Zimmer A, Nettersheim D \& Schorle H 2013 Transcription factor TFAP2C regulates major programs required for murine fetal germ cell maintenance and haploinsufficiency predisposes to teratomas in male mice. PLOS ONE 8 e71113. (doi:10.1371/journal.pone.0071113)

Seisenberger S, Andrews S, Krueger F, Arand J, Walter J, Santos F, Popp C, Thienpont B, Dean W \& Reik W 2012 The dynamics of genome-wide DNA methylation reprogramming in mouse primordial germ cells. Molecular Cell 48 849-862. (doi:10.1016/j.molcel.2012.11.001)

Sekiya S, Kawata M, Iwasawa H, Inaba N, Sugita M, Suzuki N, Motoyama T, Yamamoto T \& Takamizawa H 1985 Characterization of human embryonal carcinoma cell lines derived from testicular germ-cell tumors. Differentiation 29 259-267. (doi:10.1111/j.1432-0436.1985. tb00325.x)

Siomi MC, Sato K, Pezic D \& Aravin AA 2011 PIWI-interacting small RNAs: the vanguard of genome defence. Nature Publishing Group 12 246-258. (doi:10.1038/nrm3089)

Skakkebaek NE 1972 Possible carcinoma-in-situ of the testis. Lancet 2 516-517. (doi:10.1016/S0140-6736(72)91909-5)

Skakkebaek NE, Berthelsen JG, Giwercman A \& Muller J 1987 Carcinomain-situ of the testis: possible origin from gonocytes and precursor of all types of germ cell tumours except spermatocytoma. International Journal of Andrology 10 19-28. (doi:10.1111/j.1365-2605.1987. tb00161.x)

Skakkebaek NE, Rajpert-De Meyts E \& Main KM 2001 Testicular dysgenesis syndrome: an increasingly common developmental disorder with environmental aspects. Human Reproduction 16 972-978. (doi:10.1093/humrep/16.5.972)

Smiraglia DJ, Szymanska J, Kraggerud SM, Lothe RA, Peltomäki P \& Plass C 2002 Distinct epigenetic phenotypes in seminomatous and nonseminomatous testicular germ cell tumors. Oncogene 21 3909-3916. (doi:10.1038/sj.onc.1205488)

Sugawa F, Araúzo-Bravo MJ, Yoon J, Kim K-P, Aramaki S, Wu G, Stehling M, Psathaki OE, Hübner K \& Scholer HR 2015 Human primordial germ cell commitment in vitro associates with a unique PRDM14 expression profile. EMBO Journal 34 1009-1024. (doi:10.15252/embj.201488049)

Summersgill B, Osin P, Lu YJ, Huddart R \& Shipley J 2001 Chromosomal imbalances associated with carcinoma in situ and associated testicular germ cell tumours of adolescents and adults. British Journal of Cancer 85 213-220. (doi:10.1054/bjoc.2001.1889)

Takeuchi T, Tanigawa Y, Minamide R, Ikenishi K \& Komiya T 2010 Analysis of SDF-1/CXCR4 signaling in primordial germ cell migration and survival or differentiation in Xenopus laevis. Mechanisms of Development 127 146-158. (doi:10.1016/j.mod.2009.09.005)

Tang WWC, Dietmann S, Irie N, Leitch HG, Floros VI, Bradshaw CR, Hackett JA, Chinnery PF \& Surani MA 2015 A unique gene regulatory network resets the human germline epigenome for development. Cell 161 1453-1467. (doi:10.1016/j.cell.2015.04.053)

Thomson JA 1998 Embryonic stem cell lines derived from human blastocysts. Science 282 1145-1147. (doi:10.1126/science.282.5391.1145)

Utz DC \& Buscemi MF 1970 Extragonadal testicular tumors. Transactions of the American Association of Genito-Urinary Surgeons 62 179-182.

Verdorfer I, Rogatsch H, Tzankov A, Steiner H \& Mikuz G 2004 Molecular cytogenetic analysis of human spermatocytic seminomas. Journal of Pathology 204 277-281. (doi:10.1002/(ISSN)1096-9896)

Vogelzang NJ, Bronson D, Savino D, Vessella RL \& Fraley EF 1985 A human embryonal-yolk sac carcinoma model system in athymic mice. Cancer 55 2584-2593. (doi:10.1002/(ISSN)1097-0142)

Wang N, Trend B, Bronson DL \& Fraley EE 1980 Nonrandom abnormalities in chromosome 1 in human testicular cancers. Cancer Research $\mathbf{4 0}$ 796-802.

Wermann H, Stoop H, Gillis AJM, Honecker F, van Gurp RJHLM, Ammerpohl O, Richter J, Oosterhuis JW, Bokemeyer C \& Looijenga LHJ 2010 Global DNA methylation in fetal human germ cells and germ cell tumours: association with differentiation and cisplatin resistance. Journal of Pathology 221 433-442. (doi:10.1002/path.2725)

West JA, Viswanathan SR, Yabuuchi A, Cunniff K, Takeuchi A, Park I-H, Sero JE, Zhu H, Perez-Atayde A, Frazier AL et al. 2009 A role for Lin28 in primordial germ-cell development and germ-cell malignancy. Nature 460 909-913. (doi:10.1038/nature08210)

Western P 2009 Foetal germ cells: striking the balance between pluripotency and differentiation. International Journal of Developmental Biology 53 393-409. (doi:10.1387/ijdb.082671pw) 
Willmore-Payne C, Holden JA, Chadwick BE \& Layfield LJ 2006 Detection of c-kit exons 11- and 17-activating mutations in testicular seminomas by high-resolution melting amplicon analysis. Modern Pathology 19 1164-1169. (doi:10.1038/modpathol.3800623)

Wu S, Zhu J, Li Y, Lin T, Gan L, Yuan X, Xiong J, Liu X, Xu M, Zhao D et al. 2010 Dynamic epigenetic changes involved in testicular toxicity induced by Di-2-(Ethylhexyl) phthalate in mice. Basic and Clinical Pharmacology and Toxicology 106 118-123. (doi:10.1111/pto.2010.106.issue-2)

Xiao N, Kam C, Shen C, Jin W, Wang J, Lee KM, Jiang L \& Xia J 2009 PICK1 deficiency causes male infertility in mice by disrupting acrosome formation. Journal of Clinical Investigation 119 802-812. (doi:10.1172/ $\mathrm{JCl} 36230)$

Yao R, Ito C, Natsume Y, Sugitani Y, Yamanaka H, Kuretake S, Yanagida K, Sato A, Toshimori K \& Noda T 2002 Lack of acrosome formation in mice lacking a Golgi protein, GOPC. PNAS 99 11211-11216. (doi:10.1073/ pnas.162027899)
Zheng GXY, Ravi A, Calabrese JM, Medeiros LA, Kirak O, Dennis LM, Jaenisch R, Burge CB \& Sharp PA 2011 A latent pro-survival function for the mir-290-295 cluster in mouse embryonic stem cells. PLOS Genetics 7 e1002054. (doi:10.1371/journal.pgen.1002054)

Zhou H, Grubisic I, Zheng K, He Y, Wang PJ, Kaplan T \& Tjian R 2013 Taf7l cooperates with Trf2 to regulate spermiogenesis. PNAS $\mathbf{1 1 0}$ 16886-16891. (doi:10.1073/pnas.1317034110)

Received 7 March 2016

First decision 5 April 2016

Revised manuscript received 13 May 2016

Accepted 7 June 2016 